NASA/TM-2000-209800

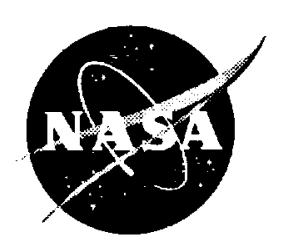

Nonprotective Alumina Growth in Sulfur-Doped $\mathrm{NiAl}(\mathrm{Zr})$

James L. Smialek

Glenn Research Center, Cleveland, Ohio 
Since its founding, NASA has been dedicated to the advancement of aeronautics and space science. The NASA Scientific and Technical Information (STI) Program Office plays a key part in helping NASA maintain this important role.

The NASA STI Program Office is operated by Langley Research Center, the Lead Center for NASA's scientific and technical information. The NASA STI Program Office provides access to the NASA STI Database, the largest collection of aeronautical and space science STI in the world. The Program Office is also NASA's institutional mechanism for disseminating the results of its research and development activities. These results are published by NASA in the NASA STI Report Series, which includes the following report types:

- TECHNICAL PUBLICATION. Reports of completed research or a major significant phase of research that present the results of NASA programs and include extensive data or theoretical analysis. Includes compilations of significant scientific and technical data and information deemed to be of continuing reference value. NASA's counterpart of peerreviewed formal professional papers but has less stringent limitations on manuscript length and extent of graphic presentations.

- TECHNICAL MEMORANDUM. Scientific and technical findings that are preliminary or of specialized interest, e.g., quick release reports, working papers, and bibliographies that contain minimal annotation. Does not contain extensive analysis.

- CONTRACTOR REPORT. Scientific and technical findings by NASA-sponsored contractors and grantees.
- CONFERENCE PUBLICATION. Collected papers from scientific and technical conferences, symposia, seminars, or other meetings sponsored or cosponsored by NASA.

- SPECIAL PUBLICATION. Scientific, technical, or historical information from NASA programs, projects, and missions, often concerned with subjects having substantial public interest.

- TECHNICAL TRANSLATION. Englishlanguage translations of foreign scientific and technical material pertinent to NASA's mission.

Specialized services that complement the STI Program Office's diverse offerings include creating custom thesauri, building customized data bases, organizing and publishing research results ... even providing videos.

For more information about the NASA STI Program Office, see the following:

- Access the NASA STI Program Home Page at $h t t p: / / w w w . s t i . n a s a . g o v$

- E-mail your question via the Internet to help@sti.nasa.gov

- Fax your question to the NASA Access Help Desk at (301) 621-0134

- Telephone the NASA Access Help Desk at (301) 621-0390

- Write to: NASA Access Help Desk NASA Center for AeroSpace Information 7121 Standard Drive Hanover, MD 21076 
NASA/TM-2000-209800

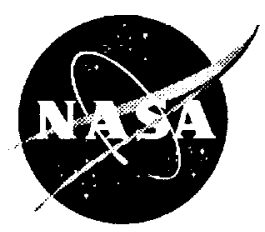

\section{Nonprotective Alumina Growth in Sulfur-Doped $\mathrm{NiAl}(\mathrm{Zr})$}

James L. Smialek

Glenn Research Center, Cleveland, Ohio

Prepared for the

Microscopy of Oxidation

sponsored by the Institute of Materials

Cambridge, United Kingdom, September 20-22, 1999

National Aeronautics and

Space Administration

Glenn Research Center 


\section{Acknowledgments}

The following are gratefully acknowledged for their excellent contributions: Ralph Garlick, XRD; John Halloran, XRF; James Smith, microprobe; Terry McCue, FEG/SEM.

Available from

NASA Center for Aerospace Information

7121 Standard Drive

Hanover, MD 21076

Price Code: A03
National Technical Information Service 5285 Port Royal Road Springfield, VA 22100 Price Code: $\mathrm{A} 03$ 


\title{
Non-Protective Alumina Growth in Sulfur-Doped NiAl(Zr)
}

\author{
James L. Smialek \\ National Aeronautics and Space Administration \\ Glenn Research Center \\ Cleveland, Ohio 44135
}

\begin{abstract}
The $1200^{\circ} \mathrm{C}$ oxidation behavior of $\mathrm{NiAl}$ was examined at various levels of sulfur and zirconium dopants to test the possibility of a critical S/Zr ratio required for adhesion. Cyclic furnace testing for 2001 -hr cycles and interrupted testing for $500 \mathrm{hr}$ were used as screening tests. Pure NiAl and $\mathrm{NiAl}(\mathrm{Zr})$ with 0.14 at.\% $\mathrm{Zr}$ were chosen as model base compositions; they exhibited normal, slow-growing scales $\left(3 \mathrm{mg} \cdot \mathrm{cm}^{-2}\right)$ with excellent adhesion for the $\mathrm{Zr}$-doped alloys. $\mathrm{NiAl}$ with about 120 ppma $S$ exhibited a substantial weight loss $\left(-20 \mathrm{mg} \cdot \mathrm{cm}^{-2}\right)$ in cyclic tests and a very large weight gain $\left(+60 \mathrm{mg} \cdot \mathrm{cm}^{-2}\right)$ in interrupted tests. The major surface phase remained as $\alpha-\mathrm{Al}_{2} \mathrm{O}_{3}$. Sulfur doping the $\mathrm{NiAl}(\mathrm{Zr})$ alloy caused massive weight gains of $80-100 \mathrm{mg} \cdot \mathrm{cm}^{-2}$, swelling, cracking, and nearly complete conversion into $\mathrm{NiAl}_{2} \mathrm{O}_{4}$ and $\alpha-\mathrm{Al}_{2} \mathrm{O}_{3}$. The initial objective of determining critical $\mathrm{S} / \mathrm{Zr}$ ratios for adhesion was therefore unattainable. Initiation of the catastrophic attack was examined after a $10 \mathrm{hr}$ exposure, revealing a few sites of broad, raised, and cracked ridges. In cross-section, the ridges appeared as nodular intrusions, with a complex, fractal, oxide-metal interface. They were primarily alumina (with occasional entrapped islands of $\mathrm{NiAl}_{2} \mathrm{O}_{4}$ or pure $\mathrm{Ni}$ metal). They possessed a unique microstructure consisting of $0.3 \mu \mathrm{m}$ lamellae, separated by $0.1 \mu \mathrm{m}$ open channels. This allowed for rapid growth controlled by gaseous diffusion. The microstructure is discussed in terms of $\mathrm{SO}_{2}$ evolution and a sulfurdriven de-passivation process.
\end{abstract}

\section{Introduction}

Alumina scale adhesion to $(\mathrm{Ni}, \mathrm{Co}, \mathrm{Fe}) \mathrm{CrAl}$ is greatly improved by small additions of reactive elements. According to the sulfur model of scale adhesion, the primary role of the dopants is to getter sulfur impurities in the metal and preclude their segregation at the oxide-metal interface and subsequent degradation of the oxide-metal bond [1]. In various tests of this theory, good adhesion has been shown to result by reducing the sulfur content $[2,3]$. For some alloys, behavior equivalent to that of reactive element doping was obtained by hydrogen annealing to extremely low sulfur levels $(0.1 \mathrm{ppmw})[4,5]$. Conversely, it has been shown that sulfur additions to an adherent, doped alloy system can destroy adhesion [6-9]. In our previous work we attempted to both show that sulfur additions could destroy adhesion for $\mathrm{NiCrAl}+\mathrm{Zr}$ alloys and to determine the critical $S / Z r$ content for adhesion for a wide range of dopant levels. In order to extend this work to the present study on $\mathrm{NiAl}$, a few levels of sulfur were added to $\mathrm{NiAl}$ with and without $\mathrm{Zr}$ dopants.

A study of sulfur-doped $\mathrm{NiAl}(\mathrm{Y})$ has shown that 270 ppma $\mathrm{S}$ increased the $\mathrm{k}_{\mathrm{p}}$ at $900^{\circ} \mathrm{C}$ by about a factor of 3 [10]. Sputter profiling Auger spectroscopy revealed sulfur segregation at the oxidemetal interface, somewhat mitigated by the presence of $Y$. Another Auger study found strong sulfur segregation to interfacial voids for $\mathrm{NiAl}+90 \mathrm{ppma} S$ at $1000^{\circ} \mathrm{C}$ [11]. And a TEM/STEM 
study of $\mathrm{NiAl}+270$ ppma $\mathrm{S}$ at $950^{\circ} \mathrm{C}$ revealed sulfur segregation at interfacial and included pores, as well as at oxide grain boundaries and intact scale-metal interfaces [12]. This study found a $4 \mathrm{x}$ increase in scale thickness and increased porosity due to sulfur doping. Accelerated (linear) internal oxidation was observed for $\mathrm{NiAl}$ oxidized in low $\mathrm{pO}_{2}$ atmospheres in the presence of sulfur impurities or $1 \% \mathrm{H}_{2} \mathrm{~S}$ [13]. Excessive scale porosity at $1200^{\circ} \mathrm{C}$ had been noted for one of the present $\mathrm{NiAl}$ alloys studied (120 ppma S) [14].

The present study examines the effects of adding $0.05 \% \mathrm{~S}$ to pure $\mathrm{NiAI}$ and $0.14 \% \mathrm{~S}$ to $\mathrm{NiAl}+$ $0.14 \% \mathrm{Zr}$. The former is intended to show only the effects of a large amount of sulfur; the second alloy is intended to show whether a stoichiometric amount of $\mathrm{S}$ and $\mathrm{Zr}$ affects adherence. It is part of a larger study examining various $\mathrm{S} / \mathrm{Zr}$ contents, but limited here to focus on a few key issues arising from the scale microstructures.

\section{Experimental}

Drop cast buttons of $\mathrm{NiAl}( \pm S, \mathrm{Zr}$ ) alloys were made by double arc melting. The intended alloy compositions and analyses by XRF and GDMS (x-ray fluorescence and glow discharge mass spectroscopy) are shown in Table I. It appears that a large amount of sulfur may be lost during processing. However the residual amount (120 ppma by GDMS, 150-300 ppma by combustion extraction analysis (Leco CS 444), and 400 ppma by XRF) is still very large compared to the nominal impurity level (1.5 ppma). (Relative standard deviations are on the order of $15 \%$ for $\mathrm{XRF}, 0.5 \%$ for combustion, and $25 \%$ for GDMS). The $\mathrm{Ni}$ and $\mathrm{Al}$ contents remained reasonably close to stoichiometric. The co-doped alloy exhibited an anomolous network, presumably breaks in the carbon film, and many $\mathrm{Zr}-\mathrm{S}$ containing precipitates, Fig. 1. Because of the small size, microprobe analyses of these particles always revealed high $\mathrm{Ni}$ and $\mathrm{Al}$ levels, Table II. The $\mathrm{S} / \mathrm{Zr}$ ratios varied from 0.01 to 0.6 , suggesting that the particles were always hyperstoichiometric with respect to $\mathrm{ZrS}$ or $\mathrm{ZrS}_{2}$. XRD analyses of as-received castings also indicated the possibility of $\mathrm{Ni}_{2} \mathrm{AlZr}$.

Oxidation of 600 grit polished coupons was performed in air at $1200^{\circ} \mathrm{C}$. Cyclic oxidation (1-hr cycles) was performed for 200 hours; interrupted oxidation was performed at $1,10,125$, and $500 \mathrm{hr}$. The scale surfaces were examined by XRD and SEM. Alloy $3(0.14 \mathrm{~S}, 0.14 \mathrm{Zr})$ was examined in cross-section after just $10 \mathrm{hr}$ of isothermal oxidation to document the early stages of consumption.

\section{Results}

The cyclic oxidation weight change data is shown in Fig. 2. The undoped alloy exhibited some scale spallation to bare metal in an otherwise grey compact layer, amounting to $-2.31 \mathrm{mg} / \mathrm{cm}^{2}$ after $200 \mathrm{hr}$. The sulfur doped sample appeared white and less compact, although it also exhibited spalling to bare metal, amounting to $-21.11 \mathrm{mg} / \mathrm{cm}^{2}$ weight change after $200 \mathrm{hr}$. Finally the $\mathrm{S} / \mathrm{Zr}$ co-doped sample gained $105.59 \mathrm{mg} / \mathrm{cm}^{2}$, appeared turquoise in color, and fractured into many pieces because of the stresses arising from excessive oxidation. The interrupted oxidation data is shown in Fig. 3, showing weight changes of $-2.20,58.54$, and 104.23 for the same three alloys after $500 \mathrm{hr}$. This is very nearly the same response as before, however now the S-doped sample shows an excessive weight gain rather than a loss. It is apparent that this high level of sulfur doping has triggered a type of catastrophic oxidation. 
Examination of the initial segments of the curves (first $80 \mathrm{hr}$ cyclic, first $125 \mathrm{hr}$ interrupted) suggest that linear oxidation rates were operative for the co-doped sample. The interrupted test also suggests a linear rate for the sulfur doped sample for the entire $500 \mathrm{hr}$. While excessive spalling for the sulfur doped sample is expected, the catastrophic linear growth rate is not. Also the co-doped sample actually had a higher catastrophic growth rate. There was no visual indication of interfacial spalling for all three samples, and no information on $\mathrm{S}$ or $\mathrm{Zr}$ effects on adhesion could be discerned. The task at hand is to explain the origin of these high rates.

The results of X-ray diffraction of the scale surfaces are shown in Table III. The scales on the undoped and sulfur-only doped samples consisted entirely of $\alpha-\mathrm{Al}_{2} \mathrm{O}_{3}$, whereas the scales on the co-doped sample were $\mathrm{NiAl}_{2} \mathrm{O}_{4}$ spinel and $\alpha-\mathrm{Al}_{2} \mathrm{O}_{3}$, with little difference between the cyclic and interrupted tests. While a higher oxidation rate might be expected for spinel scales on the co-doped samples, the XRD results do not explain the high rates on the sulfur-only doped sample.

The large weight change and the kinetic slowing after $125 \mathrm{hr}$ for the co-doped sample suggest that this sample may be reaching total consumption after $500 \mathrm{hr}$, Fig. 3. From the reaction:

$$
\mathrm{NiAl}+5 / 2 \mathrm{O}_{2}=\mathrm{NiO}+1 / 2 \mathrm{Al}_{2} \mathrm{O}_{3}
$$

one can calculate the weights of the resultant products after complete reaction given the initial weight of the sample and the $\mathrm{Ni}, \mathrm{Al}$ concentrations. For this sample, initially $1.58 \mathrm{gm}$, the amount of $\mathrm{NiO}$ product would be $1.40 \mathrm{gm}$ and the amount of $\mathrm{Al}_{2} \mathrm{O}_{3}$ would be $0.90 \mathrm{gm}$. The total product was therefore calculated to be $2.31 \mathrm{gm}$, as compared to the measured $2.09 \mathrm{gm}$ final weight, or $\sim 90 \%$ converted on a weight change basis.

After just $10 \mathrm{hr}$ of oxidation (isothermal), the $\mathrm{S} / \mathrm{Zr}$ co-doped sample still gained $9.0 \mathrm{mg} / \mathrm{cm}^{2}$ and the scale was determined by XRD to be primarily $\alpha-\mathrm{Al}_{2} \mathrm{O}_{3}$, with a minor amount of $\mathrm{NiAl}_{2} \mathrm{O}_{4}$. Examination of the surface revealed essentially flat, dark grey regions of adherent oxide, with a network of ridges, perhaps decorating some grain boundaries. Occasional growth nodules also existed in isolation from the network. Details of such a ridge are shown in the SEM micrographs of Fig. 4. Figure 4(a) shows one leg of a ridge network, having severe cracking down the midrib or spline and bright outlines at the growth boundary between the ridge and unaffected scale. The highlighting arises from uplifted scale segments and spalling to bare metal at this boundary. In backscatter mode, Fig. 4(b), the ridge areas exhibit a finely spaced network of cracks (C), grey $(\mathrm{Ni}, \mathrm{Al})$-rich oxide patches $(\mathrm{S})$, and bright $\mathrm{Ni}$-oxide nodules $(\mathrm{N})$, all dispersed in a matrix of dark Al-oxide (from EDS).

These structures were analyzed in more detail from a polished cross-section. At low magnification, the ridge sections show very deep oxide intrusions with a complex growth front, cracks, and a number of dispersed phases, Figs. 5 and 6 . The various phases were analyzed by standardless EDS, Table IV: the bright areas were entrapped islands of Ni metal, the main dark intrusions were alumina, and the grey patches were $\mathrm{NiAl}_{2} \mathrm{O}_{4}$ spinel. (The exact stoichiometry was not obtained and the apparent chemistry was somewhat dependent on accelerating voltage).

In the residual, peninsular metal regions, $\mathrm{Al}$ depletion was detected up to $\sim 50 \mu \mathrm{m}$ ahead of the oxide interface. In other areas ahead of the growth fingers, very little $\mathrm{Al}$ depletion was noted (43\% Al remained at positions 2.5 and $9.5 \mu \mathrm{m}$ ahead of the intrusion in Fig. 7(a), compared to 
$53 \%$ at the center of the sample). Moderate and uniform depletion is also suggested by the occurrence of martensitic striations to a depth of at least $50 \mu \mathrm{m}$ ahead of these protrusions. $\mathrm{NiAl}$ martensite is possible only for aluminum levels above $30 \%$ [15].

The BSE images in Fig. 7 also illustrate the complex interface of the alumina intrusions with indications of porosity (Fig. 7(a)). The interface is further seen as a columnar structure of oxide fibrils and continuous porosity, Fig. 7(b), with lateral dimensions on the order of 0.1-0.3 $\mu \mathrm{m}$. Finally, at low $\mathrm{kV}$, even finer porosity $(0.05 \mu \mathrm{m})$ can be discerned within the primary pore network, Fig. 8. The basic picture is that of a porous, nonprotective oxide growing into the metal so fast and irregularly that it encapsulates islands of unreacted metal. These eventually react with incoming oxygen and the adjacent alumina matrix to form isolated regions of mixed oxides (spinel).

The sulfur-only doped sample was also oxidized for an intermediate time (125 hr). The scale top surface (Fig. 9(a)) and bottom surface (Fig. 9(b)) both contained a high degree of porosity, again suggesting a nonprotective scale microstructure. However this scale does not appear to grow into the metal with the unstable interface characteristic of the $S / Z r$ co-doped sample. The reasons for this and the lower weight gain compared to the co-doped sample are not clear.

\section{Discussion}

A model is now proposed to account for the extensive porosity that may give rise to the catastrophic growth rates. It is based on the consumption of a layer of $\mathrm{NiAl}$ in reacting with a given amount of oxygen and the reaction of the amount of sulfur contained in this layer to form $\mathrm{SO}_{2}$ gas. For the density of alumina given as $3.98 \mathrm{gm} / \mathrm{cm}^{2}$ and $\mathrm{NiAl}$ as $5.86 \mathrm{gm} / \mathrm{cm}^{2}$, it can be shown that for every $1 \mathrm{mg} / \mathrm{cm}^{2}$ of weight gain (of oxygen):

$1.124 \mathrm{mg} / \mathrm{cm}^{2}$ of $\mathrm{Al}$ is reacted

$2.124 \mathrm{mg} / \mathrm{cm}^{2}$ of $\mathrm{Al}_{2} \mathrm{O}_{3}$ is formed, $(5.33 \mu \mathrm{m})$

$3.57 \mathrm{mg} / \mathrm{cm}^{2}$ of $\mathrm{NiAl}$ is affected, $(6.00 \mu \mathrm{m})$.

Thus for a sulfur concentration of $120 \mathrm{ppma}(88 \mathrm{ppmw})$, it can be shown that $9.8 \mathrm{moles} / \mathrm{cm}^{2}$ of sulfur are released for every $1 \mathrm{mg} / \mathrm{cm}^{2}$ of oxygen gained. Using the ideal gas law and fixing $\mathrm{P}$ at $1 \mathrm{~atm}$, then the volume of $\mathrm{SO}_{2}$ can be calculated, yielding a gas layer thickness of $11.8 \mu \mathrm{m}$. This value is twice the thickness of the corresponding scale formed and strongly suggests that this amount of sulfur can contribute significantly to porosity. Conversely, if the relative volume of porosity, i.e., $\mathrm{SO}_{2}$, is fixed at $20 \%$, then the corresponding pressure is calculated to be 11.1 atm., again implying a strong influence on pore formation. It should be recalled, however, that upwards of $100 \mathrm{mg} / \mathrm{cm}^{2}$ weight gain was achieved, so the layer thickness calculated above for $1 \mathrm{mg} / \mathrm{cm}^{2}$ weight gain must all be scaled upward by a factor of 100 .

The general process can be described in terms of a growth interface schematic, Fig. 10. Here sulfur segregates to the oxide-metal interface as the NiAl layer reacts with oxygen to form $\mathrm{Al}_{2} \mathrm{O}_{3}$. Some back diffusion of sulfur may accommodate the additional sulfur released, but sulfide growth was not observed and the matrix is already saturated. The build-up continues until it may react with incoming oxygen to form $\mathrm{SO}_{2}$. The $\mathrm{SO}_{2}$ formed occupies a substantial volume at high pressure and prevents complete interface passivation from the $\mathrm{Al}_{2} \mathrm{O}_{3}$. These depassivated regions 
are then propagated as the relief valves for further sulfur evolution, developing into widespread porosity and microchannels. Depassivation may initially be produced by the intrinsic chemical properties of adsorbed sulfur and maintained by the physical gas evolution process. Chemical depassivation is widely observed in low temperature aqueous corrosion of transition metals having adsorbed or segregated sulfur monolayers [16]. The interconnected pores then serve as rapid paths for gaseous oxygen transport, allowing the oxidation process to be controlled by interface reaction kinetics (sulfur, oxygen, and aluminum surface rearrangements) rather than slow solid state diffusion in $\mathrm{Al}_{2} \mathrm{O}_{3}$.

This situation is only valid if indeed the scale is completely porous and allows full access of oxygen to the interface with a $\mathrm{pO}_{2}=0.2 \mathrm{~atm}$. If the scale seals off the interface, then the $\mathrm{pO}_{2}$ is determined by the $\mathrm{NiAl}-\mathrm{Al}_{2} \mathrm{O}_{3}$ equilibrium and will be less than $\sim 10^{-25}$ atm at $1200^{\circ} \mathrm{C}$. For the reaction:

$$
\begin{gathered}
\mathrm{S}+\mathrm{O}_{2}=\mathrm{SO}_{2} \\
\mathrm{~K}=\left(\mathrm{p}_{\mathrm{SO} 2} / \mathrm{p}_{\mathrm{O} 2}\right) / \mathrm{a}_{\mathrm{S}}
\end{gathered}
$$

It can be seen that a low value of $\mathrm{pO}_{2}$ will define a low value of $\mathrm{pSO}_{2}$. Thus the high gas pressures or volumes discussed above would not apply, and another means of creating porosity would be needed.

Rapid, linear, nonprotective growth of $\mathrm{Al}_{2} \mathrm{O}_{3}$ scales in $\mathrm{NiAl}$ has been observed at low $\mathrm{pO}_{2}$ for $700-1000^{\circ} \mathrm{C}$ oxidation [13]. The presumed presence of sulfur impurities (from a Rhines pack) or in sulfur-containing gases $\left(1 \% \mathrm{H}_{2} \mathrm{~S}\right)$ was required to prevent the formation of a healing layer of $\mathrm{Al}_{2} \mathrm{O}_{3}$. In some cases cones of oxide penetration were formed with a coarse lamellar structure of $\mathrm{Ni}$ metal and $\mathrm{Al}_{2} \mathrm{O}_{3}$ platelets. In other cases deep penetrating fingers of oxide grew into the alloy. This internal oxidation was predicated on the formation of a $\mathrm{Ni}$-depletion zone ahead of the oxidation front.

There are similarities and differences with the present work. Nonprotective $\mathrm{Al}_{2} \mathrm{O}_{3}$, a tortuous oxidation front, and sulfur as the responsible depassivating agent are all common factors. The requirement of a low $\mathrm{pO}_{2}$ environment and a Ni-depletion zone for internal oxidation is not shared by the present study. Also no role of microporosity was apparent in the prior study. While sulfur plays an important role in both instances, the mechanism for rapid growth (internal oxidation versus microporosity) does not appear to be the same.

There are other instances of nonprotective scale growth due to rapid diffusion through structural features in other alumina and silica-forming systems. The $1200^{\circ} \mathrm{C}$ oxidation of AIN in moist oxygen was found to be linear, achieving $48 \mathrm{mg} / \mathrm{cm}^{2}$ in $48 \mathrm{hr}$ [17]. The microstructure contained a large fraction of fine $50-300 \mathrm{~nm}$ pores, Fig. 11. These presumably resulted from the evolution of $\mathrm{N}_{2}$ gas released from the substrate and acted as fast diffusion paths for oxygen.

In low temperature $\left(723^{\circ} \mathrm{C}\right)$ oxidation of $\mathrm{NbAl}_{3}$-based alloys, selective oxidation of aluminum allows $\mathrm{Al}_{2} \mathrm{O}_{3}$ to form, but back diffusion of $\mathrm{Nb}$ into the alloy does not occur rapidly enough [18]. The result is an internal oxide composed of intermingled $20 \mathrm{~nm}$ lamellae of denuded metallic $\mathrm{Nb}$ and $\alpha-\mathrm{Al}_{2} \mathrm{O}_{3}$. The oxide-metal interface and pure $\mathrm{Nb}$ act as rapid paths for oxygen diffusion. Thus low temperature, linear, accelerated oxidation is the result (e.g., $10 \mathrm{mg} / \mathrm{cm}^{2}$ weight gain after $600 \mathrm{hr}$ at $700^{\circ} \mathrm{C}$ ). 
Finally, $\mathrm{MoSi}_{2}$ was found to exhibit linear, accelerated oxidation at $500^{\circ} \mathrm{C}$, producing $2.3 \mathrm{mg} / \mathrm{cm}^{2}$ in $50 \mathrm{hr}$ [19]. The scale consisted of interminged amorphous $\mathrm{SiO}_{2}$ and nonprotective $\mathrm{MoO}_{2}$ lamellae only $10 \mathrm{~nm}$ wide. Again the protective scale phase is discontinuous and nonhealing, and the product microstructure contains ultra-fine columnar features to serve as rapid diffusion paths. The latter two accelerated oxidation processes could only be discerned through the use of TEM techniques. They provide a critical step necessary for pest reactions, in addition to structural defects, for the $\mathrm{NbAl}_{3}$ and $\mathrm{MoSi}_{2}$ intermetallic compounds, as originally proposed by Doychak and co-workers.

\section{Summary and Conclusions}

This study has documented some unusual behavior observed during the oxidation of highly sulfur-doped NiAl. While the presence of $\mathrm{Zr}$ dopants did result in numerous $\mathrm{Zr}$-S precipitates due to the gettering ability of $\mathrm{Zr}$, no additional information was provided that directly impacts scale adhesion theory or the sulfur effect. Instead, instances of rapid, linear, nonprotective oxidation were found, even though $\alpha-\mathrm{Al}_{2} \mathrm{O}_{3}$ was the primary scale phase. In the case of the $\mathrm{S} / \mathrm{Zr}$ co-doped $\mathrm{NiAl}$, the scale grew with an unstable interface geometry into a hypostoichiometric $\beta$-NiAl. As islands of metal were encompassed by the advancing front, Al-depletion to levels as low as $10 \%$ (down from $50 \%$ ) was observed, resulting ultimately in local $\mathrm{NiAl}_{2} \mathrm{O}_{4}$ formation. Final weight gains exceeded $100 \mathrm{mg} / \mathrm{cm}^{2}$ as would be the case for complete consumption of the sample. The rapid oxidation appeared to result from a porous scale microstructure, where submicron open channels served as paths for rapid gas transport. In one mechanism, it is suggested that the high level of sulfur in the alloy accumulates at the oxidation front, produces local depassivation, evolves $\mathrm{SO}_{2}$ at a high gas pressure and volume, and is ultimately responsible for these microchannels. If the pores are not continuous, the $\mathrm{SO}_{2}$ pressures will not be high and this mechanism would not apply.

\section{References}

1. A.W. Funkenbusch, J.G. Smeggil, and N.S. Bornstein, "Reactive Element-Sulfur Interaction and Oxide Scale Adherence," Metall. Trans. A, 1985, 16, 164-1166.

2. J.G. Smeggil, "Some Comments on the Role of Yttrium in Protective Oxide Scale Adherence," Mater. Sci. Engineer., 1987, 87, 261-265.

3. J.L. Smialek, "Effect of Sulfur Removal on $\mathrm{Al}_{2} \mathrm{O}_{3}$ Scale Adhesion," Metall. Trans. A, 1991, 22, 739-752.

4. J.L. Smialek, D.T. Jayne, J.C. Schaeffer, and W.C. Murphy, "Effect of hydrogen annealing, sulfur segregation and diffusion on the cyclic oxidation resistance of superalloys: a review," Thin Solid Films, 1994, 253, 285-292.

5. J.L. Smialek, "Toward Optimum Scale and TBC Adhesion on Low Sulfur Superalloys," High Temperature Corrosion and Materials Chemistry, 98-9 Symp. Proc., P.Y. Hou, M.J. McNallan, R. Oltra, E.J. Opila, D.A. Shores, eds., The Electrochemical Society, Pennington, NJ, 1998, 211-220.

6. J.G. Smeggil, A.W. Funkenbusch, and N.S. Bornstein, "A Relationship Between Indigenous Impurity Elements and Protective Oxide Scale Adherence Characteristics," Metall. Trans. A, 1986, 17, 923-932. 
7. W.J. Quadakkers, C. Wasserfuhr, A.S. Khanna, and H. Nickel, "Influence of sulfur impurity on oxidation behavior of Ni-10Cr-9Al in air at $1000^{\circ} \mathrm{C}$," Mat. Sci. Techn., 1988, 4, $1119-1125$.

8. A.S. Khanna, H. Jonas, and W.J. Quadakkers, "Use of acoustic emission technique to study the spalling behavior of oxide scales on $\mathrm{Ni}-10 \mathrm{Cr}-8 \mathrm{Al}$ containing sulphur and/or yttrium impurity," Werkstoffe und Korrosion, 1989, 40, 552-558.

9. J.L. Smialek, "The Effect of Sulfur and Zirconium Co-doping on the Oxidation of NiCrAl," Proceedings of High Temp. Materials Chemistry IV, Z.A. Munir, D. Cubicciotti, and $\mathrm{H}$ Tagawa, eds., Electrochem. Soc., 1988, 241-253 .

10. P.A. van Manen, C.J. vander Wekken, C.A. vander Paardt, and J.H.W deWit, "The adhesion of oxide scales on NiAl alloys," $11^{\text {th }}$ International Corrosion Congress, Ass. Ital. Di Metall., Milan, 1990, 1, 449-460.

11. H.J. Grabke, D. Wiemer, and H. Viefhaus, "Segregation of sulfur during growth of oxide scales," Appl. Surf. Sci., 1991, 47, 243-250.

12. K. Prüßner, E. Schumann, and M. Rühle, "Oxidation of S-doped $\beta-\mathrm{NiAl}$ in $\mathrm{H}_{2} / \mathrm{H}_{2} \mathrm{O}$ and in Air," Electrochemical Society Proceedings, 1996, 96-26, 344-356.

13. H.J. Grabke and G.H. Meier, "Accelerated oxidation, internal oxidation, intergranular oxidation, and pesting of intermetallic compounds," Oxidation of Metals, 1995, 44, $147-176$.

14. J.L. Smialek, "Sulphur Impurities and the Microstructure of Alumina Scales," Microscopy of Oxidation, S.B. Newcomb and J.A. Little, eds., Inst. of Mat., London, 1996, 4, 127-139.

15. J.L. Smialek, "Transformation Temperatures of Nickel Aluminide Martensite," Met. Trans., $1973,4,1571-1575$.

16. P. Marcus and J. Oudar, "Surface Modification by Chemisorbed Sulfur," Fundamental Aspects of Corrosion Protection, E. McCafferty, C.R. Clayton, and J. Oudar, eds., Electrochem. Soc., Pennington,NJ, 1984, 173-193.

17. E.J. Opila, N.S. Jacobson, D. Humphrey, K. Oda, "The Oxidation of AIN in Dry and Wet Oxygen," High Temperature Corrosion and Materials Chemistry, 98-9 Symp. Proc., P.Y. Hou, M.J. McNallan, R. Oltra, E.J. Opila, D.A. Shores, eds., Electrochem. Soc., Pennington, NJ, 1998, 431-437.

18. J. Doychak, S.V. Raj, I.E. Locci, and M.G. Hebsur, "Accelerated Oxidation of $\mathrm{NbAl}_{3}$ Alloys at Intermediate Temperatures," NASA CP-10082, 1991, 18:1-11.

19. J.L. Smialek, J.A. Nesbitt, W.J. Brindley, M.P. Brady, J. Doychak, R.M. Dickerson, and D.R. Hull, "Service Limitations for Oxidation Resistant Intermetallic Compounds," Materials Research Society Symposium, 1995, 364, 1273-1284.

TABLE I.-COMPOSITIONS OF SELECTED S/Zr DOPED NiAI ALLOYS

[Atomic percent; or ppma where indicated.]

\begin{tabular}{|c|c|c|c|c|c|c|}
\hline $\begin{array}{c}\text { Alloy } \\
\text { number }\end{array}$ & $\mathrm{Ni}, \mathrm{XRF}$ & $\mathrm{Al}, \mathrm{XRF}$ & $\mathrm{Zr}, \mathrm{XRF}$ & $\mathrm{S}, \mathrm{XRF}$ & $\mathrm{S}$, Leco & S, GDMS \\
\hline 1 & 51.4 & 48.6 & $\begin{array}{c}0.00 \\
(0.00)\end{array}$ & $\begin{array}{c}0.00 \\
(0.00)\end{array}$ & $\leq 0.0001$ & $\begin{array}{c}0.0001 \\
1.5 \mathrm{ppma}\end{array}$ \\
\hline 2 & 51.2 & 48.8 & $\begin{array}{c}0.00 \\
(0.00)\end{array}$ & $\begin{array}{c}0.040 \\
(0.05)\end{array}$ & 0.024 & $\begin{array}{c}0.013 \\
130 \mathrm{ppma}\end{array}$ \\
\hline 3 & 51.3 & 48.5 & $\begin{array}{c}0.160 \\
(0.14)\end{array}$ & $\begin{array}{c}0.037 \\
(0.14)\end{array}$ & 0.039 & $\begin{array}{c}0.032 \\
320 \mathrm{ppma}\end{array}$ \\
\hline
\end{tabular}

(Melt addition). 
TABLE II.-MICROPROBE ANALYSIS OF SULFUR-DOPED NiAl+Zr (atomic \%)

[NiAl-3, 0.14 Zr + 0.14 S.]

\begin{tabular}{|l|c|c|c|c|c|}
\hline & $\mathrm{Ni}$ & $\mathrm{Al}$ & $\mathrm{Zr}$ & $\mathrm{S}$ & $\mathrm{S} / \mathrm{Zr}$ \\
\hline undoped NiAl-1 & 48 & 52 & 0.01 & 0.05 & \\
\hline & & & & & \\
\hline NiAl-3 matrix & 48 & 52 & 0.03 & 0.05 & \\
\hline network & 48 & 52 & 0.02 & 0.01 & \\
\hline & & & & & \\
\hline precipitates: & & & & & \\
\hline rectangular (g) & 47 & 33 & 20 & 0.2 & 0.01 \\
\hline elliptical (c1) & 44 & 34 & 18 & 0.2 & 0.01 \\
\hline elliptical (c2) & 44 & 34 & 23 & 4.4 & 0.16 \\
\hline fine cluster (f) & 43 & 45 & 8 & 4.2 & 0.55 \\
\hline stringer (d) & 37 & 32 & 22 & 8.4 & 0.39 \\
\hline
\end{tabular}

TABLE III.-XRD ANALYSIS OF SCALE PHASES, $1200^{\circ} \mathrm{C}$, IN AIR

\begin{tabular}{|l|c|c|}
\hline \multicolumn{1}{|c|}{ Alloy } & Cyclic, 200 hr & Interrupted, 500 hr \\
\hline $\mathrm{NiAl}-1$ & $\mathrm{Al}_{2} \mathrm{O}_{3}$ & $\mathrm{Al}_{2} \mathrm{O}_{3}$ \\
\hline $\mathrm{NiAl}-6$ & $\mathrm{Al}_{2} \mathrm{O}_{3}$ & $\mathrm{Al}_{2} \mathrm{O}_{3}$ \\
\hline $\mathrm{NiAl}-3$ & $\mathrm{NiAl}_{2} \mathrm{O}_{4}, \mathrm{Al}_{2} \mathrm{O}_{3}$ & $\begin{array}{c}\mathrm{NiAl}_{2} \mathrm{O}_{4}, \mathrm{Al}_{2} \mathrm{O}_{3}, \\
\left(\mathrm{ZrO}_{2}, \mathrm{NiO}\right)\end{array}$ \\
\hline
\end{tabular}

TABLE IV.-EDS ANALYSIS OF METAL AND SCALE PHASES, NiAl-3: $0.14 \mathrm{~S}, 0.14 \mathrm{Zr} ; 10 \mathrm{hr}$ at $1200^{\circ} \mathrm{C}$ [Atomic percent, standardless ZAF corrections.]

\begin{tabular}{|c|c|c|c|c|}
\hline \multirow{2}{*}{\multicolumn{5}{|c|}{$6 \mathrm{kV}$, no carbon }} \\
\hline & & & & \\
\hline Bright metal islands & 75 to 85 & 5 to 15 & 10 & $y-\mathrm{Ni}-10 \mathrm{Al}$ \\
\hline Interface metal, $<10 \mu \mathrm{m}$ & 64 & 26 & 0.5 & $\gamma^{\prime}-\mathrm{Ni}-29 \mathrm{Al}$ \\
\hline In depletion zone, $30 \mu \mathrm{m}$ & 54.6 & 30.25 & 0.7 & $\beta-\mathrm{Ni}-35 \mathrm{Al}$ \\
\hline Out of depletion, $230 \mu \mathrm{m}$ & 44.1 & 42.3 & 4.6 & $\beta-\mathrm{Ni}-49 \mathrm{Al}$ \\
\hline Centerline & 47.8 & 44.8 & 3.2 & $\beta-\mathrm{Ni}-48 \mathrm{Al}$ \\
\hline Dark alumina matrix & 0.4 & 36 & 63 & $\mathrm{Al}_{2} \mathrm{O}_{3.5}$ \\
\hline Grey spinel islands & 16 & 22 & 62 & $\mathrm{NiO} \cdot \mathrm{Al}_{2} \mathrm{O}_{4}$ \\
\hline \multicolumn{5}{|l|}{$10 \mathrm{kV}$, carbon coat } \\
\hline Dark alumina matrix & --- & 45 & 55 & $\mathrm{Al}_{2} \mathrm{O}_{2.5}$ \\
\hline Grey spinel islands & 14 & 33 & 53 & $\mathrm{NiO} \cdot \mathrm{Al}_{2} \mathrm{O}_{2.4}$ \\
\hline
\end{tabular}



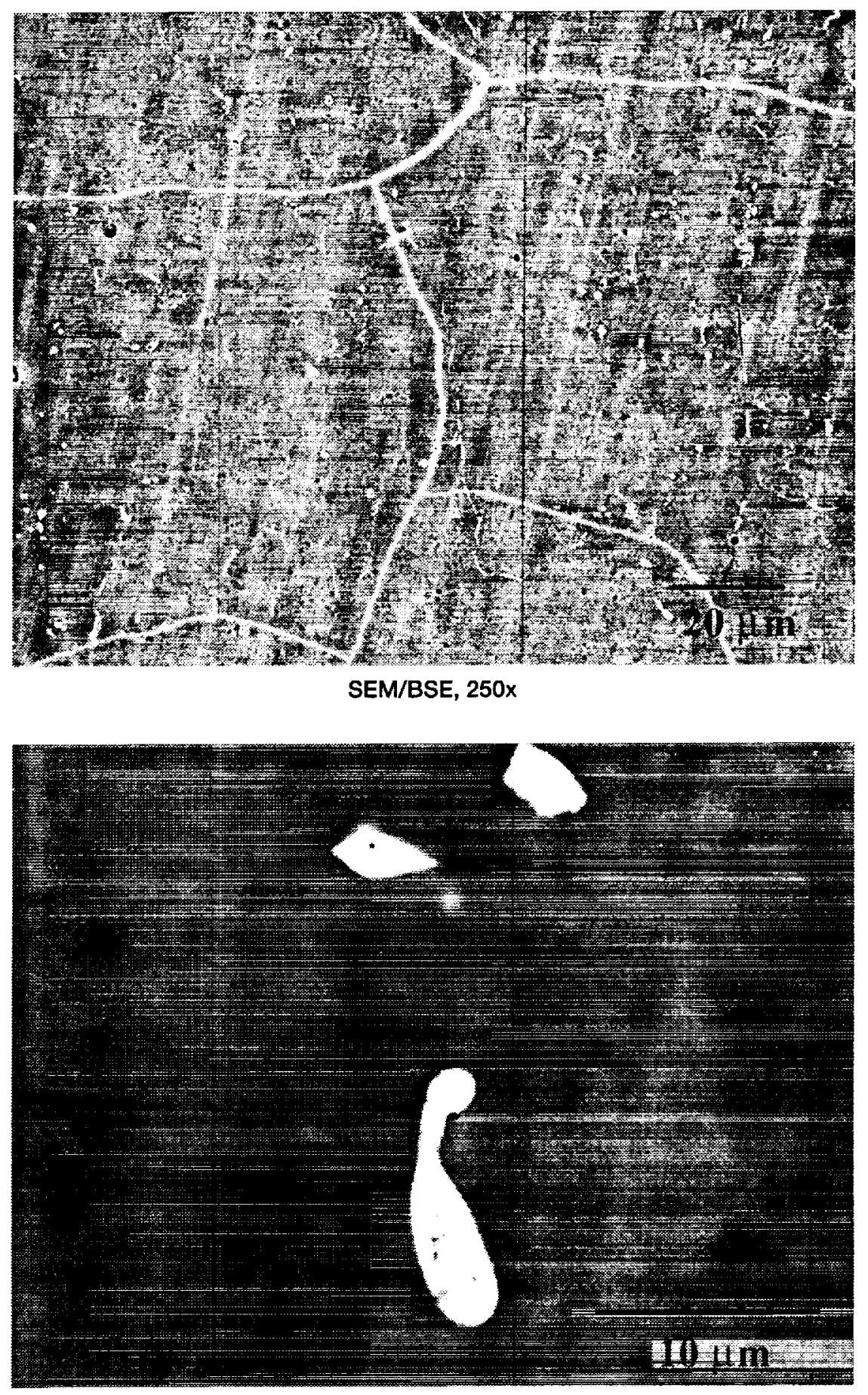

SEM/BSE, 3000x

Figure 1.-As-cast microstructures. NiAl-3, $0.14 \mathrm{Zr}+0.14 \mathrm{~S}$. Bright network and dispersed $\mathrm{Zr}$-rich $\mathrm{Ni}_{2} \mathrm{AlZr}$ precipitates. 


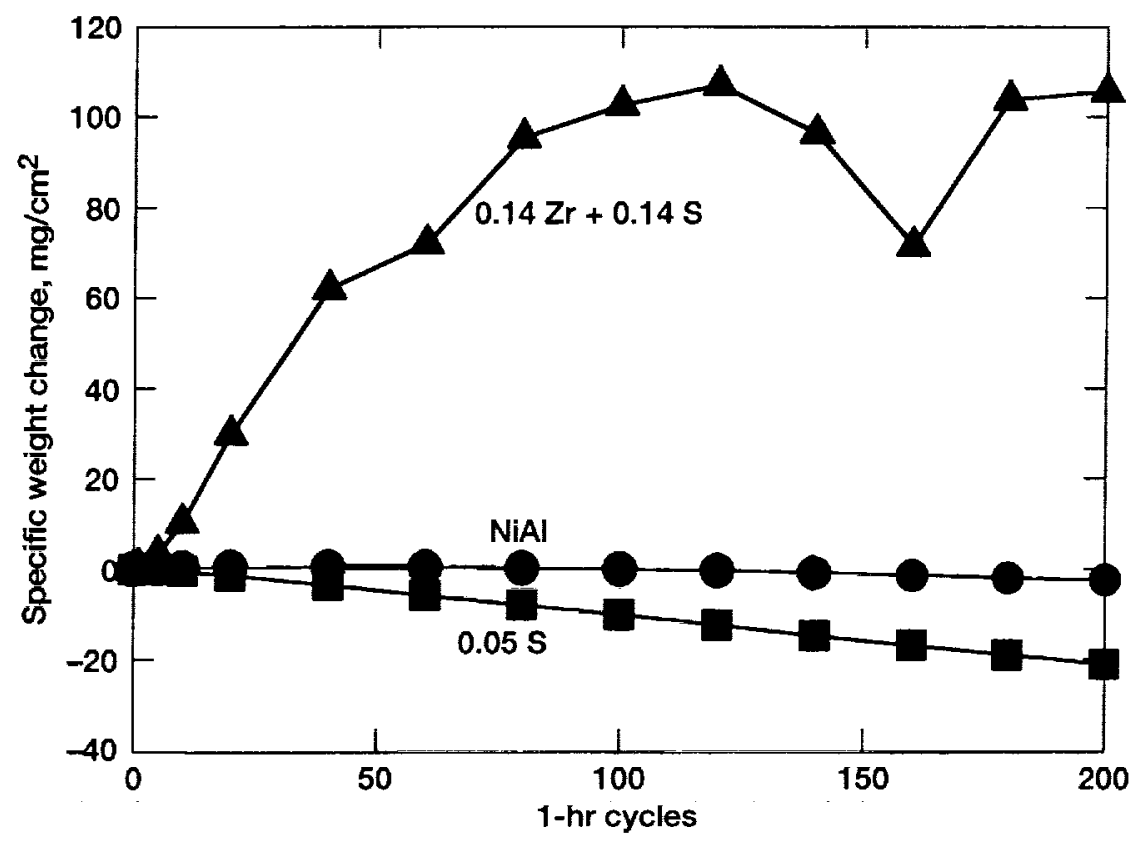

Figure 2.-Effect of sulfur doping on $1200^{\circ} \mathrm{C}$ cyclic oxidation.

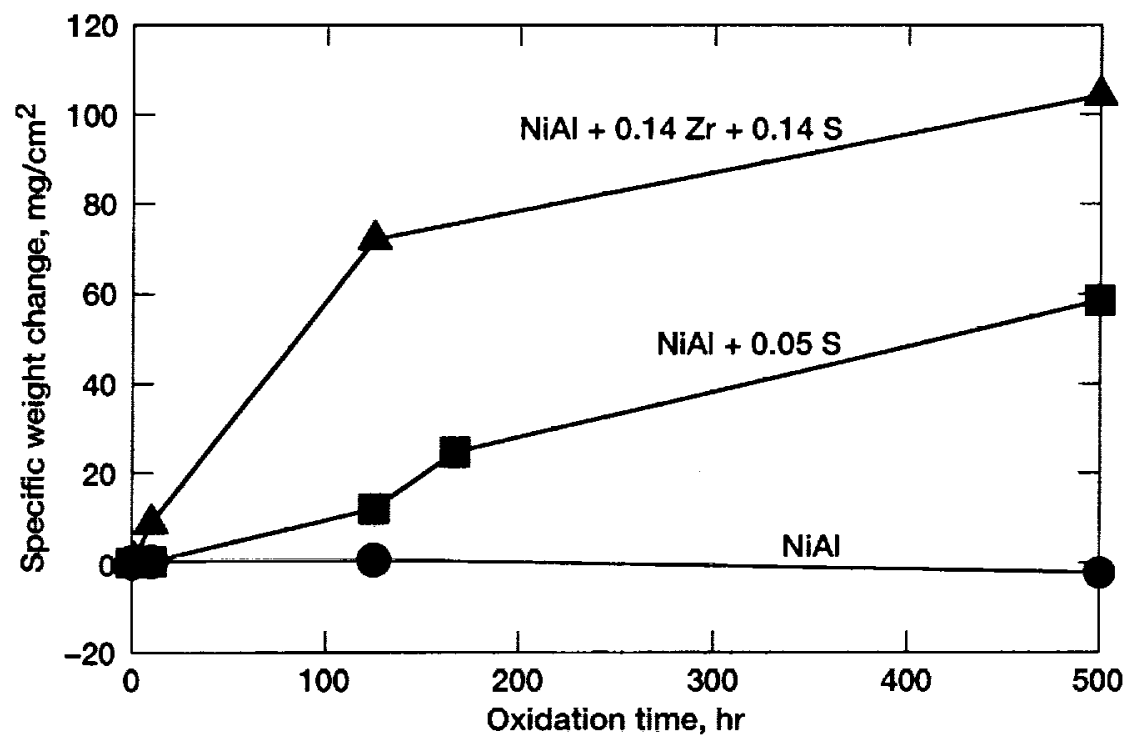

Figure 3.-Effect of sulfur doping on $1200^{\circ} \mathrm{C}$ internupted oxidation. 


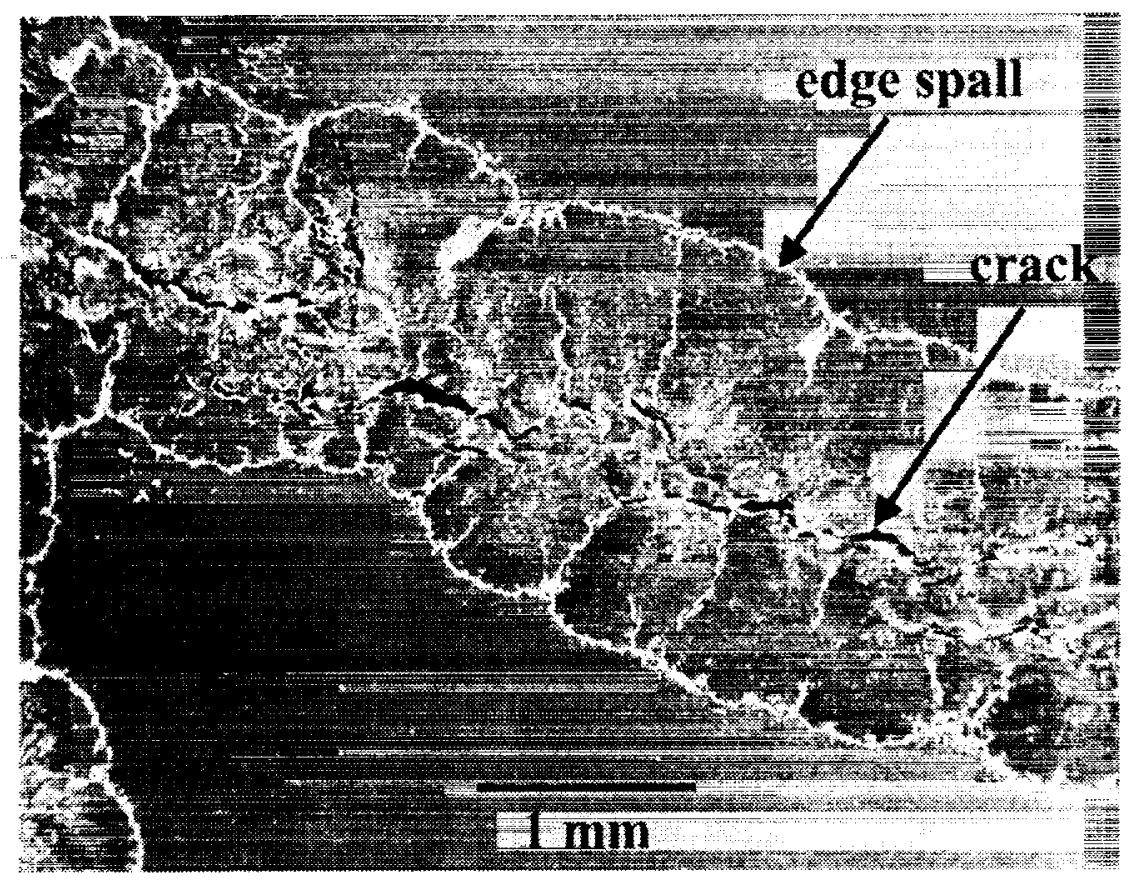

SEM/SE, 20x initiation ridge

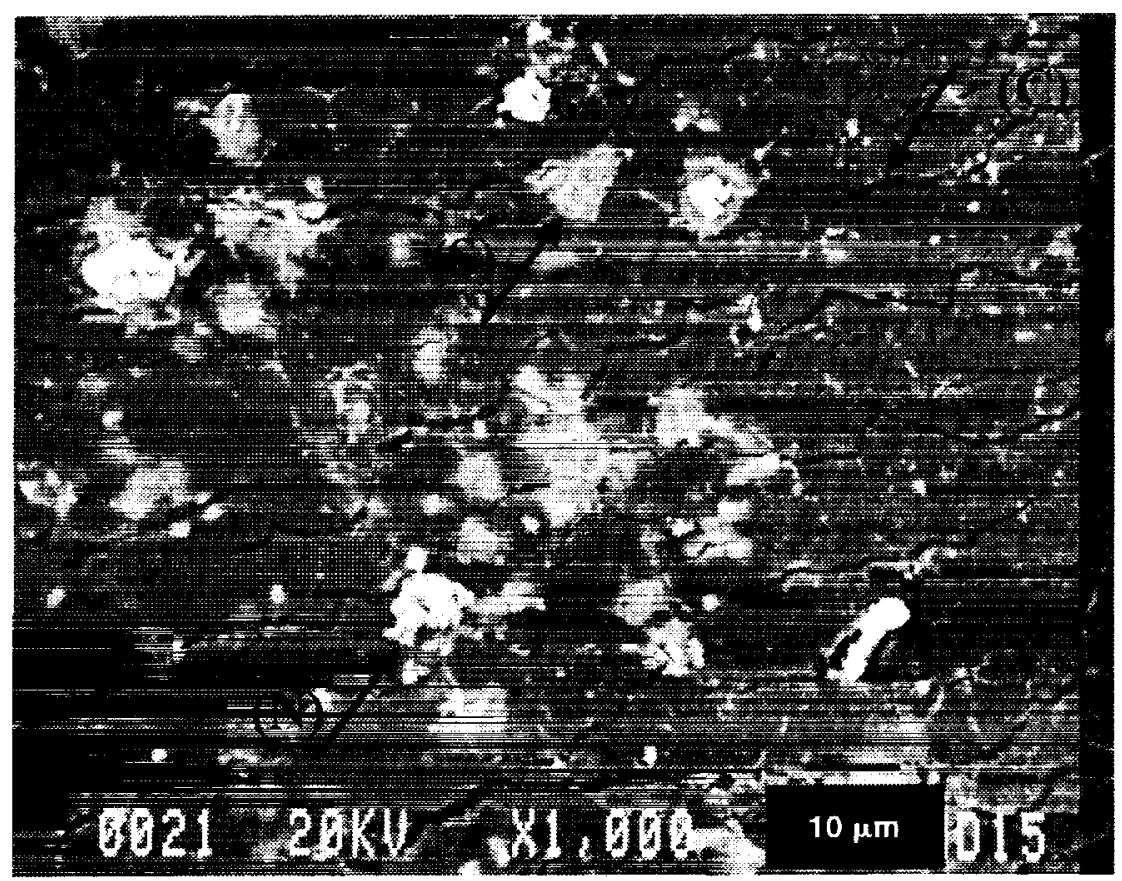

SEM/BSE, $1000 \times$ local $\mathrm{NiO}$ and $\mathrm{NiAl}_{2} \mathrm{O}_{4}$ regions

Figure 4.-Incipient degradation of $\mathrm{NiAl}-3,0.14 \mathrm{Zr}+0.14 \mathrm{~S} ; 10 \mathrm{hr}$ at $1200^{\circ} \mathrm{C}$. Swelling, cracking, spalling, and Ni-oxide formation. 


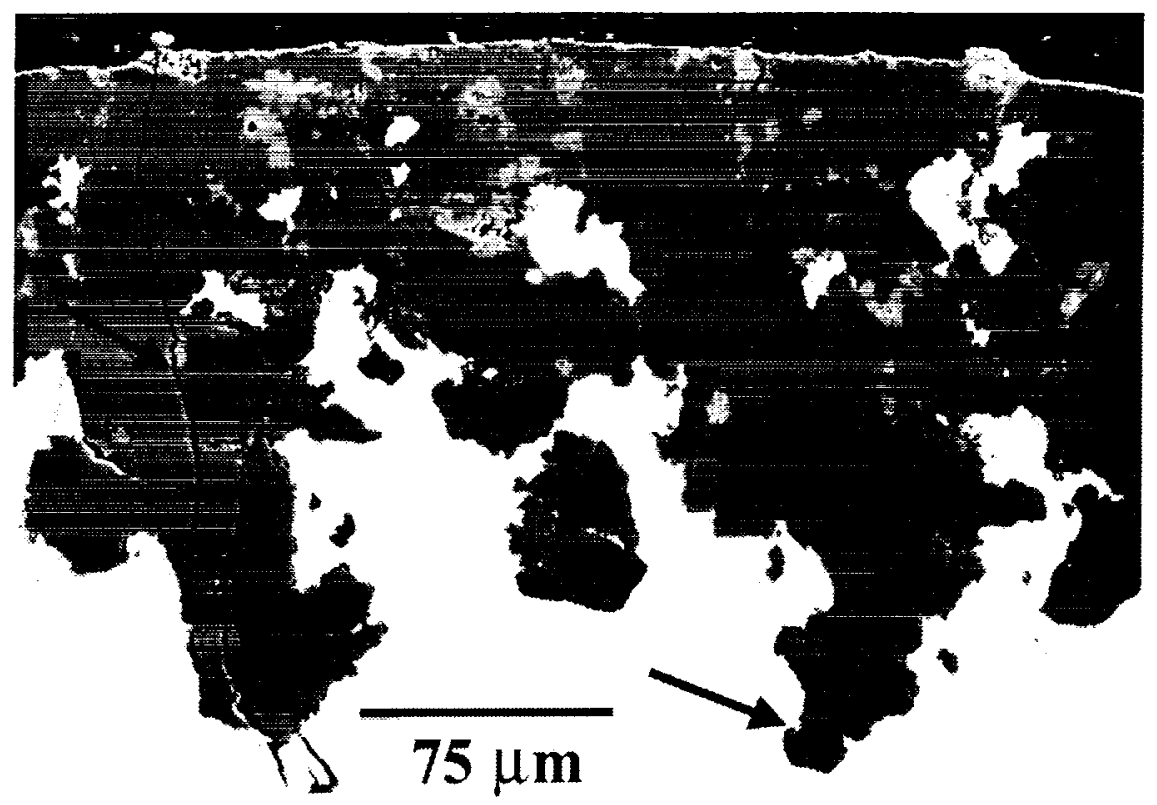

Figure 5.-Fractal intrusions and cracking at mid-spline of oxide ridge. NiAl-3: $0.14 \mathrm{Zr}+0.14 \mathrm{~S} ; 1200^{\circ} \mathrm{C}, 10 \mathrm{hr}$.

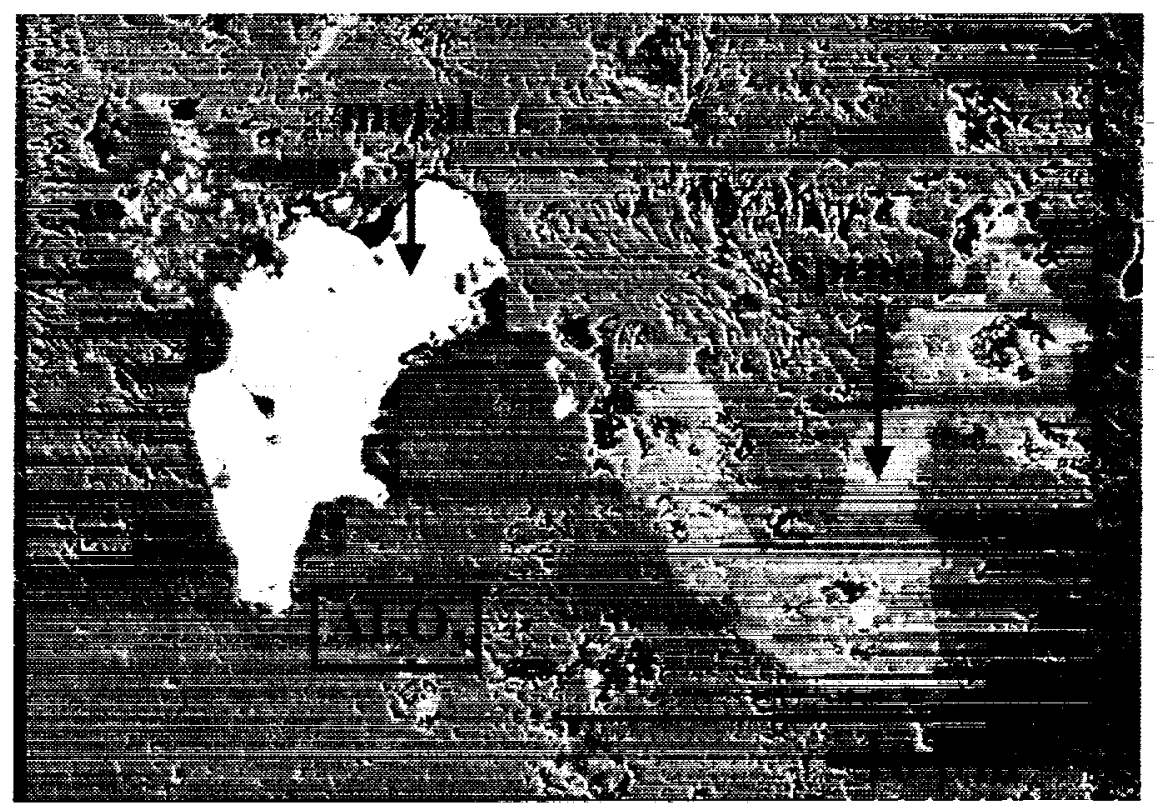

Figure 6. Entrapped $\mathrm{Ni}$, Ni-Al-O regions. NiAl-3: $0.14 \mathrm{Zr}+0.14 \mathrm{~S} ; 1200^{\circ} \mathrm{C}$, $10 \mathrm{hr}$. 

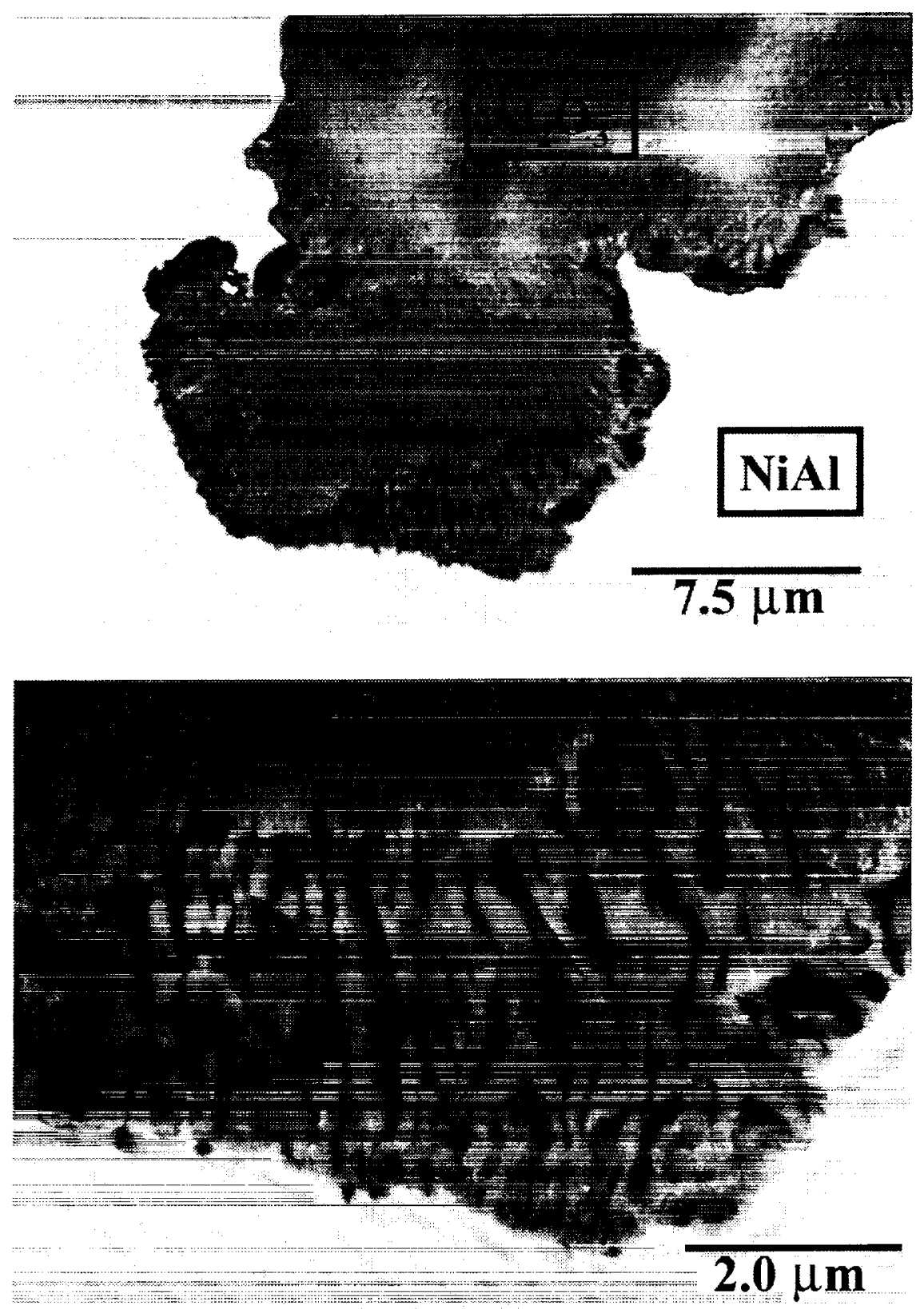

Figure 7.-Tip of fibrous $\mathrm{Al}_{2} \mathrm{O}_{3}$ intrusion. NiAl-3: $0.14 \mathrm{Zr}+0.14 \mathrm{~S} ; 1200{ }^{\circ} \mathrm{C}$, $10 \mathrm{hr}$. 


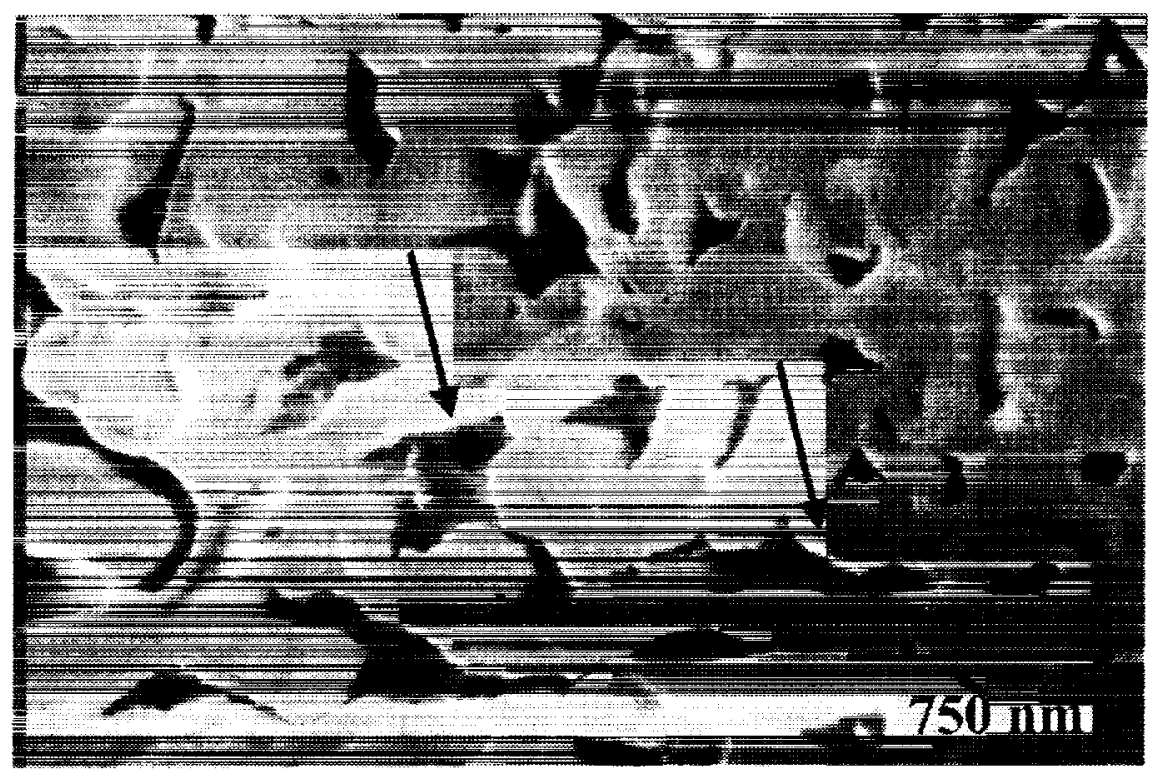

Figure 8. $-\mathrm{Al}_{2} \mathrm{O}_{3}$ microchannels. NiAl-3: $0.14 \mathrm{Zr}+0.14 \mathrm{~S} ; 1200^{\circ} \mathrm{C}, 10 \mathrm{hr}$. 

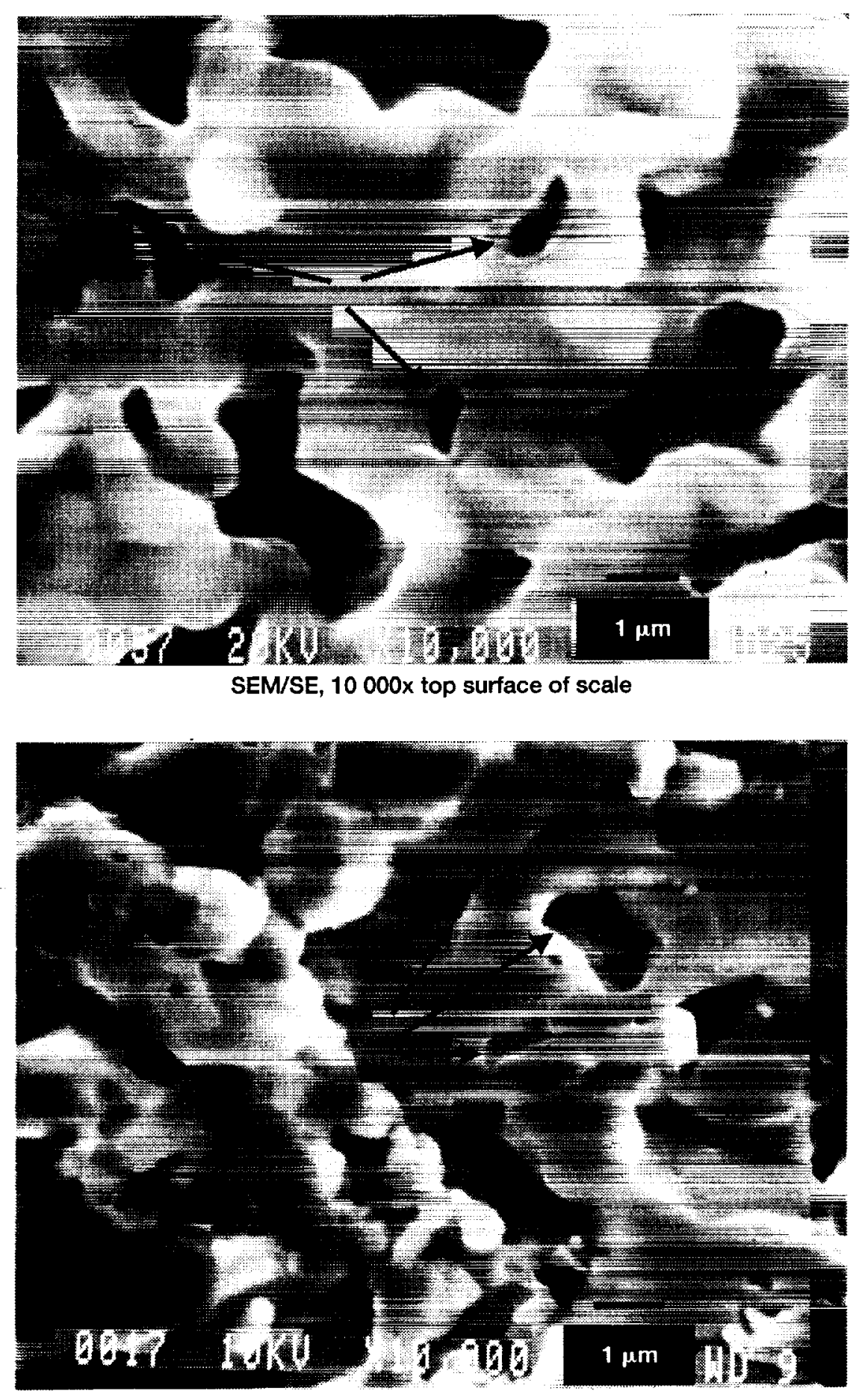

SEM/SE, $10000 \times$ bottom of stripped scale

Figure 9.-Porous surfaces of unprotective $\mathrm{Al}_{2} \mathrm{O}_{3}$ scales. NiAl-6, $0.05 \mathrm{~S}$; $1200^{\circ} \mathrm{C}, 125 \mathrm{hr}$. 


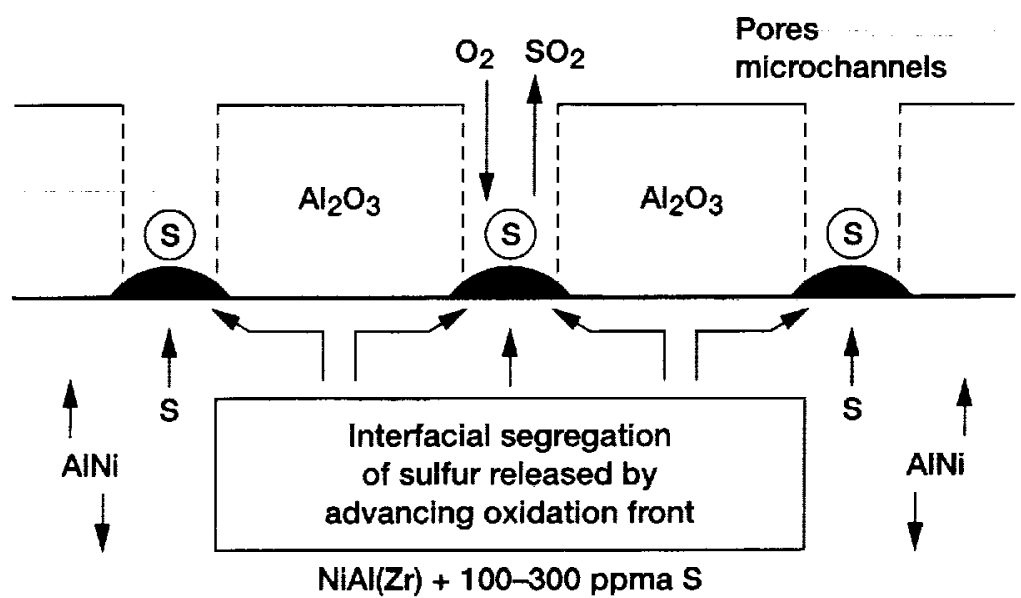

Figure 10.- Sulfur accumulation and gas generation model.

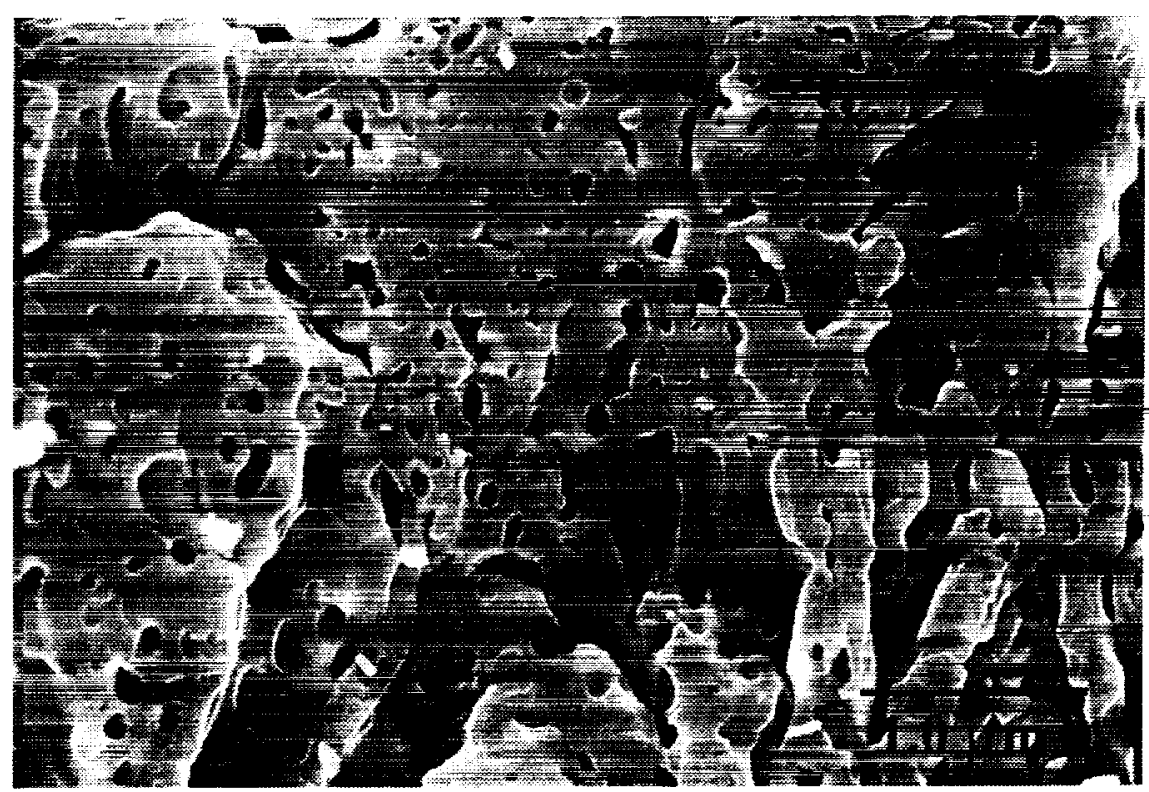

Figure 11.-Microporosity in $\mathrm{Al}_{2} \mathrm{O}_{3}$ scale on AIN. $10 \% \mathrm{H}_{2} \mathrm{O} / \mathrm{O}_{2}, 1200{ }^{\circ} \mathrm{C}, 48 \mathrm{hr}$; Opila 1999 (ref. 17). 
,

;

$!$ 
Public reporting burden for this coliection of information is estimated to average t hour per response, including the time for reviewing instructions, searching existing data sources, gathering and maintaining the data needed, and completing and reviewing the collection of information. Send comments regarding this burden estimate or any other aspect of this collection of information, including suggestions for reducing this burden, to Washington Headquarters Services, Directorate for Information Operations and Reports, 1215 Jeffers Davis Highway, Suite 1204, Arlington, VA 22202-4302, and to the Otlice of Management and Budget, Paperwork Reduction Project (0704-0188), Washington, DC 20503.

\begin{tabular}{|l|l|l} 
1. AGENCY USE ONLY (Leave blank) & $\begin{array}{c}\text { 2. REPORT DATE } \\
\text { March } 2000\end{array}$ & $\begin{array}{r}\text { 3. REPORT TYPE AND DATES COVERED } \\
\text { Technical Memorandun }\end{array}$
\end{tabular}

\section{TITLE AND SUBTITLE}

Nonprotective Alumina Growth in Sulfur-Doped $\mathrm{NiAl}(\mathrm{Zr})$
5. Fur

\section{AUTHOR(S)}

James L. Smialek

$$
\text { WU }-714-04-20-00
$$

\section{PERFORMING ORGANIZATION NAME(S) AND ADDRESS(ES)}

National Aeronautics and Space Administration

John H. Glenn Research Center at Lewis Field

Cleveland, Ohio 44135-3191

8. PERFORMING ORGANIZATION REPORT NUMBER

E-12100

9. SPONSORING/MONITORING AGENCY NAME(S) AND ADDRESS(ES)

10. SPONSORINGMONITORING AGENCY REPORT NUMBER

National Aeronautics and Space Administration

Washington, DC 20546-0001

NASA TM-2000-209800

\section{SUPPLEMENTARY NOTES}

Prepared for the Microscopy of Oxidation sponsored by the Institute of Materials, Cambridge, United Kingdom, September 20-22, 1999. Responsible person, James L. Smialek, organization code 5160, (216) 433-5500.

12a. DISTRIBUTION/AVAILABILITY STATEMENT

12b. DISTRIBUTION CODE

Unclassified-Unlimited

Subject Category: 26

Distribution: Nonstandard

This publication is available from the NASA Center for AeroSpace Information, (301) 621-0390.

13. ABSTRACT (Maximum 200 words)

The $1200^{\circ} \mathrm{C}$ oxidation behavior of $\mathrm{NiAl}$ was examined at various levels of sulfur and zirconium dopants to test the possibility of a critical S/Zr ratio required for adhesion. Cyclic furnace testing for 2001 -hr cycles and interrupted testing for $500 \mathrm{hr}$ were used as screening tests. Pure $\mathrm{NiAl}$ and $\mathrm{NiAl}(\mathrm{Zr})$ with 0.14 at.\% $\mathrm{Zr}$ were chosen as model base compositions; they exhibited normal, slow-growing scales $\left(3 \mathrm{mg} \cdot \mathrm{cm}^{-2}\right)$ with excellent adhesion for the $\mathrm{Zr}$-doped alloys. NiAl with about 120 ppma $S$ exhibited a substantial weight loss $\left(-20 \mathrm{mg} \cdot \mathrm{cm}^{-2}\right)$ in cyclic tests and a very large weight gain $\left(+60 \mathrm{mg} \cdot \mathrm{cm}^{-2}\right)$ in interrupted tests. The major surface phase remained as $\alpha-\mathrm{Al}_{2} \mathrm{O}_{3}$. Sulfur doping the $\mathrm{NiAl}(\mathrm{Zr})$ alloy caused massive weight gains of $80-100 \mathrm{mg} \cdot \mathrm{cm}^{-2}$, swelling, cracking, and nearly complete conversion into $\mathrm{NiAl}_{2} \mathrm{O}_{+}$and $\alpha-$ $\mathrm{Al}_{2} \mathrm{O}_{3}$. The initial objective of determining critical $\mathrm{S} / \mathrm{Zr}$ ratios for adhesion was therefore unattainable. Initiation of the catastrophic attack was examined after a $10 \mathrm{hr}$ exposure, revealing a few sites of broad, raised, and cracked ridges. In cross-section, the ridges appeared as nodular intrusions, with a complex, fractal, oxide-metal interface. They were primarily alumina (with occasional entrapped islands of $\mathrm{NiAl}_{2} \mathrm{O}_{4}$ or pure $\mathrm{Ni}$ metal). They possessed a unique microstructure consisting of $0.3 \mu \mathrm{m}$ lamellae, separated by $0.1 \mu \mathrm{m}$ open channels. This allowed for rapid growth controlled by gaseous diffusion. The microstructure is discussed in terms of $\mathrm{SO}_{2}$ evolution and a sulfur-driven de-passivation process.

14. SUBJECT TERMS

Oxidation; High temperature alloys; $\mathrm{NiAl}$; Sulfur segregation; $\mathrm{Al}_{2} \mathrm{O}_{3}$ scales

15. NUMBER OF PAGES 22

16. PRICE CODE

\section{$\mathrm{A} 03$}

17. SECURITY CLASSIFICATION
OF REPORT
Unclassified

18. SECURITY CLASSIFICATION
OF THIS PAGE
Unclassified

19. SECURITY CLASSIFICATION OF ABSTRACT Unclassified 